\author{
Author's Reply
}

\section{Reply to Comment on: Hales CN, Ozanne SE (2003) For Debate: Fetal and early postnatal growth restriction lead to diabetes, the metabolic syndrome and renal failure}

To the Editor: We are grateful to Plagemann et al. for their constructive comments on wider aspects of the field we discussed in our article. The title and main substance of our article was a factual summary of the results of our experiments on rats, involving feeding rat dams a low-protein diet during pregnancy and lactation. This manipulation results in fetal and early postnatal growth restriction. It was not our intention to review all of the literature in this field, but rather, in an invited lecture, to review the progress of our own research. We apologise if we caused unrest by the focus of our article. We did not state that low birthweight is a cause of adult obesity, although there are data to suggest that this is true in some circumstances.

We entirely agree with Plagemann et al. that the roles played by changes in fetal growth, and indeed the time points during pregnancy at which these changes occur, need to be systematically investigated. These studies will need to distinguish between infants of high birthweight who are normally developed and those who are macrosomic [1]. The possible contribution of changes in early postnatal growth to adult disease also needs to be addressed. In our most recent experiments we have sought to distinguish between the effects of fetal growth restriction and early postnatal growth restriction, and this has produced some startling results [2]. It will also be important to determine which changes in postnatal growth are due to antenatal programming, for example programmed overexpression of the insulin receptor [3], and which are induced by the postnatal environment, for example overfeeding.

DOI 10.1007/s00125-004-1445-0

Received: 29 April 2004 / Accepted: 4 May 2004

Published online: 8 July 2004

(C) Springer-Verlag 2004
It has been known for many years through manipulation of litter size that, in the rat, nutrition during the lactation period has long-term effects on appetite [4]. We have shown recently that programming of appetite during this period in the mouse is powerful enough to prevent early excess weight gain in response to a highly palatable diet [5].

It is gratifying that the discovery of strong links between early human growth and adult risk of Type 2 diabetes [6] and the metabolic syndrome [7] have shown the great importance of this area of research in understanding these health problems.

C. N. Hales · S. E. Ozanne

Department of Clinical Biochemistry, University of Cambridge, Level 4, Addenbrooke's Hospital, Cambridge, UK

\section{References}

1. McCance DR, Pettitt DJ, Hanson RL et al. (1994) Birth weight and non-insulin dependent diabetes: 'thrifty genotype', 'thrifty phenotype', or 'surviving small baby genotype'. BMJ 308:942-945

2. Ozanne SE, Hales CN (2004) Catch-up growth and obesity in male mice. Nature 427:411-412

3. Ozanne SE, Wang CL, Coleman N et al. (1996) Altered muscle insulin sensitivity in the male offspring of protein malnourished rats. Am J Physiol 271:E1128-E1134

4. Oscai LP, McGarr JA (1978) Evidence that the amount of food consumed in early life fixes appetite in the rat. Am J Physiol 235:R141-R144

5. Ozanne SE, Lewis R, Jennings BJ, Hales CN (2004) Early programming of weight gain in mice prevents the induction of obesity by a highly palatable diet. Clin Sci 106:141-145

6. Hales CN, Barker DJP, Clark PMS et al. (1991) Fetal and infant growth and impaired glucose tolerance at age 64 years. BMJ 303:1019-1022

7. Barker DJP, Hales CN, Fall CHD et al. (1993) Type 2 (noninsulin-dependent) diabetes mellitus, hypertension and hyperlipidaemia (syndrome $\mathrm{X}$ ): relation to reduced fetal growth. Diabetologia 36:62-67

C. N. Hales (

Department of Clinical Biochemistry,

University of Cambridge, Level 4, Addenbrooke's Hospital,

Hills Road, Cambridge, CB2 2QR, UK

E-mail: cnh1000@cam.ac.uk

Tel.: +44-1223-336787, Fax: +44-1223-762563/330598 